\title{
Biological factors impacting hydrological processes: Pecularities of plants and biological soil crusts
}

\author{
Giora J. Kidron ${ }^{1}$, Maik Veste ${ }^{2}$, L'ubomír Lichner ${ }^{3}$ \\ ${ }^{1}$ Institute of Earth Sciences, The Hebrew University of Jerusalem, Givat Ram Campus, 91904 Jerusalem, Israel. \\ E-mail: kidron@mail.huji.ac.il \\ ${ }^{2}$ Institute of Environmental Sciences, Soil Protection and Recultivation, Brandenburg University of Technology Cottbus-Senftenberg, \\ Konrad-Wachsmann-Allee 6, 03046 Cottbus, Germany. E-mail: maik.veste@b-tu.de \\ ${ }^{3}$ Institute of Hydrology, Slovak Academy of Sciences, Dúbravská cesta 9, 84104 Bratislava, Slovakia. E-mail: lichner@uh.savba.sk
}

The effects of biological factors on the water cycle and subsequently on hydrological processes have wide and profound consequences on ecosystem structure, function and management. A profound understanding of their effects is of prime importance especially in light of climate change projection.

Whether regarding water infiltration or release (via evapotranspiration), the water cycle is central for the assessment of ecosystem services provided by soil (Vereecken et al., 2016). With soil being a home to about $25 \%$ of all living species on Earth (Turbé et al., 2010), the interrelationship soil-biota has large consequences, beyond the obvious effects on the hydrology, pedology or ecology. Geologists for instance believe that the biota is involved in the formation of $2 / 3$ of about 4300 known minerals (Hazen et al., 2008). The biota, especially plants and microorganisms, plays a central role in geomorphological processes, a field currently termed biogeomorphology (Corenblit et al., 2011). Among the microorganisms and small organisms that may fundamentally affect the water dynamics are biological soil crusts, also known as biocrusts, which are composed of variable proportions of autotrophs (cyanobacteria, green algae, lichens, mosses, liverworts) accompanied by heterotrophs such as fungi, bacteria and archaea (Belnap and Lange, 2003).

As far as plants are concerned, water consumption facilitates photosynthesis and growth, as well as evapotranspiration, along with numerous biochemical reactions. Water provides the necessary turgor and facilitates the mechanism whereby leaf cooling takes place (Ehlers and Goss, 2003). Plants may have also indirect effects. Thus, by water (whether rain or dew and fog) interception (Miralles et al., 2010; Simonin et al., 2009), or their impact on infiltration, whether by increasing infiltration (Lange et al., 2009) or partially hindering it through water repellency (WR) (Doerr et al., 2000; Lichner et al., 2010). Plants may affect runoff, thus hindering runoff generation and flow (Cerdà, 1997). They may also affect the water cycle by impacting the microclimate (e.g. Gillner et al., 2015; Kidron, 2009).

As far as the microorganisms are concerned, they may increase surface temperatures (Harper and Marble, 1988), the water-holding capacity (Chenu, 1993), aggregation and subsequently infiltration (Or et al., 2007), but also hinder infiltration due to WR (Lichner et al., 2013) or pore clogging (Kidron et al., 1999). As for plants, while most processes are in consensus and the research nowadays mainly focuses on the study of species-specific process-dependent rates (Callaway, 1998; Klanderud, 2008), the possible effects of climate change (Root et al., 2003), and the development of models aiming to increase our understanding in future anticipation of the hydrological cycle following climate change (Vereecken et al., 2016), the effects of biocrusts on the hydrological processes are not in consensus, triggering ongoing discussions. The small-size organisms that constitute the crusts along with the close cellsoil association exert extra difficulties in clearly pinpointing at the exact hydrological mechanism. Not only that disagreement exists regarding some of the mechanisms, but even regarding the values involved, with reported differences of up to two orders of magnitude also from the very same research site, as is the case with dew.

Among the controversial issues are the use of dew as a possible water source for biocrusts and the effects of biocrusts on infiltration, runoff and evaporation. As far as dew is concerned, the reported values that presumably are available for biocrusts are of a wide range, even for the same research site, such as for the Hallamish dunefield in the Negev (Littmann and Veste, 2008). While one group of researchers reported daily values of up to $0.5 \mathrm{~mm}$ (Heusinkveld et al., 2006), another group reported maximum daily values of $0.1-0.3 \mathrm{~mm}$ (Veste et al., 2008), while a third group reported substantially lower values with an average value of only $0.034 \mathrm{~mm}$ (Kidron et al., 2002). As far as evaporation is concerned, while some researchers maintain that biocrusts impede evaporation, therefore playing a positive role upon plant growth (Eldridge et al., 2020), other maintain the opposite, i.e., an increase in evaporation and subsequently a decrease in soil moisture, resulting in a negative effect of biocrusts on the soil water regime and hence on plant growth and fecundity (Kidron, 2019).

While research on species-specific effects of biocrusts is still in its infancy, efforts are made to characterize the variable effects of the different crust types, mainly cyanobacterial, lichen- and moss-dominated crusts, which, may be considered as keystone groups for the biocrust microcosm. Similarly to the main species of vascular plants that disproportionally to their distribution primarily control the structure and function of the ecosystem, these keystone groups may largely determine numerous processes of the biocrust microcosm and among them hydrological processes.

During the current special issue, papers devoted to elucidate the impact of biological factors on the hydrological processes are presented. The papers include the effects of humans ( 1 paper), plants ( 3 papers) and biocrusts (6 papers). As for the effect of humans, Balashov et al. (2021) checked the possible effect of adding two types of biochars to soil on the soil moisture and $\mathrm{N}_{2} \mathrm{O}$ emission of two soil types, reporting differences in accordance with the biochar type and quantity and in accordance with soil type. 
As for the effect of plants, Zabret and Šraj (2021) and Jančo et al. (2021) examined the effect of trees on rainfall interception. Examining birch and pine trees in Slovenia, Jančo et al. (2021) found that rain duration and intensity largely control the interception, as well as the phenoseason, i.e., whether or not leaves are present on the tree canopy. Examining spruce trees in Slovakia, Jančo et al. (2021) measured the magnitude of the rain interception in relation to the crown architecture, i.e., the central crown zone near the stem, the crown periphery and the canopy gap. Leelamanie et al. (2021) examined the hydrophobic effect of three types of trees (Eucalyptus, Pine, Casuarina) planted in Sri Lanka. All granted high hydrophobicity to the soils, especially during the summer. All the above-mentioned papers have important consequences on infiltration and runoff.

Most of the special issue is devoted to research on biocrusts. While Muselli and Beysens (2021) focused on the occurrence of dew, all other five papers dealt with the effects of biocrusts on surface hydrology. Using meteorological parameters, Muselli and Beysens (2021) used an energy balance model developed by Beysens (2016) aiming to calculate dew yield. The authors used data gathered from 18 meteorological stations scattered throughout southern Africa to construct a map with dew distribution. By comparing the calculated dew data to rain precipitation, the authors proposed that dew yield may compensate for the decline in rain precipitation during the last decade (2010-2020), and may therefore explain the fact that no decrease in biocrust cover was reported following the decrease in rain precipitation.

Under greenhouse conditions, Thielen et al. (2021) investigated the effect of 5 species of mosses taken from forests of central Europe on the maximum water storage and evaporation. Moss structure was found to affect water storage and all mosses were found to retard evaporation. Factors that may affect infiltration and runoff were studied by Drahorad et al. (2021) and Guan and Liu (2021). Drahorad et al. (2021) investigated possible factors that may determine WR. The authors compared biocrusts from a temperate region in Slovakia and an arid region in the Negev. With mosses exhibiting higher WR than cyanobacterial crusts and the dunes in Slovakia exhibiting higher WR than that of the Negev, the authors conclude that WR is triggered by organic matter while diminishing by the higher amounts of calcium carbonate, dust, and subsequently higher $\mathrm{pH}$ of the Negev dunes. Moss-dominated biocrusts not only increase WR as found by these authors, but also increase water-holding capacity and subsequently decrease infiltration, as found by Guan and Liu (2021) in the Mu Us Desert in China. By using disc infiltrometer, Guan and Liu conducted infiltration experiments evaluating the various hydrological parameters which were found to be substantially affected by crust development.

The effect of different crust types on the flow length of runoff was studied by Lázaro et al. (2021) in the Tabernas Desert in Spain. Aiming to quantify the minimum runoff length (mRL), i.e., the effective contributing area in which runoff coefficient equals 1 of three crust types, cyanobacterial, early successional and late successional lichen crusts, the authors report on interesting results. Proposing that mRL may serve a proxy for RL, the authors found that while $\mathrm{mRL}$ was up to 3.3 $4.0 \mathrm{~m}$ on a cyanobacterial biocrust, it was $2.2-7.5 \mathrm{~m}$ in the early successional lichen crust and only $1.0-1.5 \mathrm{~m}$ on late successional lichen crust, generally indicating a decrease in $\mathrm{mRL}$ with an increase in crust biomass.

Kidron (2021) presented a mini review that challenged some of the wide-spread views concerning the driving factors responsible for runoff generation over biocrusts in arid and semiarid regions. While WR was found to play an important role in temperate humid regions, the author claims that no conclusive data were yet reported on the involvement of WR in runoff in arid and semiarid regions. Other wide-spread views that explained runoff over biocrusts such as structure, texture, surface roughness are also challenged, claiming that they cannot explain runoff initiation which succeeds surface saturation, and is responsible in turn to infiltration-excess overland flow (also known as Hortonian overland flow, HOF). Extracellular polymeric substances (EPS) are suggested to play a major role in partial surface clogging and subsequently in runoff initiation - a prerequisite factor for HOF.

The combined efforts by ecologists and hydrologists, as manifested in this thematic issue, may help to increase our understanding regarding the interrelations between plants, biocrusts and hydrological processes. Obviously, as also manifested during this special volume, there are still issues in dispute and not in consensus. Bringing them to the forefront is a prerequisite step which may trigger additional research focusing on 'open' non-consensus issues, and may thus advance our understanding in ecosystem structure, function and management.

\section{REFERENCES}

Balashov, E., Buchkina, N.P., Šimanský, V., Horák, J., 2021. Effects of slow and fast pyrolysis biochar on $\mathrm{N}_{2} \mathrm{O}$ emissions and water availability of two soils with high water-filled pore space. J. Hydrol. Hydromech., 69, 4, 467-474.

Belnap, J., Lange, O.L. (Eds.), 2003. Biological Soil Crusts: Structure, Function, and Management. Revised 2nd Printing. Springer Publisher, Berlin.

Beysens, D., 2016. Estimating dew yield worldwide from a few meteo data. Atmos. Res., 167, 146-155.

Callaway, R.M., 1998. Are positive interactions speciesspecific? Oikos, 82, 202-207.

Cerdà, A., 1997. The effect of patchy distribution of Stipa tenacissima L. on runoff and erosion. J. Arid Environ., 36, 37-51.

Chenu, C., 1993. Clay- or sand- polysaccharide associations as models for the interface between micro-organisms and soil: water related properties and microstructure. Geoderma, 56, $143-156$.

Corenblit, D., Baas, A.C.W., Bornette, G., Darrozes, J., Delmotte, S., Francis, R.A., Gurnell, A.M., Julien, F., Naiman, R.J., Streiger, J., 2011. Feedbacks between geomorphology and biota controlling Earth surface processes and landforms: A review of foundation concepts and current understanding. Earth-Sci. Rev., 106, 307-331. https://doi.org/10.1016/j.earscirev.2011.03.002

Doerr, S.H., Shakesby, R.A., Walsh, R.P.D., 2000. Soil water repellency: its causes, characteristics and hydrogeomorphological significance. Earth-Sci. Rev., 51, 33-65. https://doi.org/10.1016/S0012-8252(00)00011-8

Drahorad, S.L., Felde, V.J.M.N.L., Ellerbrock, R.H., Henss, A., 2021. Water repellency decreases with increasing carbonate content and $\mathrm{pH}$ for different biocrust types on sand dunes. J. Hydrol. Hydromech., 69, 4, 369-377.

Ehlers, W., Goss, M.J., 2003. Water Dynamics in Plant Production. CABI Publishing. Wallingford, UK.

Eldridge, D.J., Reed, S., Travers, SK., Bowker, M.A., Maestre, F.T., Ding, J., Havrilla, C., Rodriguez-Caballero, E., Barger, N., Weber, B., Antoninka, A., Belnap, J., Chaudhary, B., Faist, A., Ferrenberg, S., Huber-Sannwald, E., Malam Issa, O., Zhao, Y., 2020. The pervasive and multifacetal influence 
of biocrusts on water in the world's drylands. Glob. Change Biol., 26, 6003-6014. https://doi.org/10.1111/gcb.15232

Gillner, S., Vogt, J., Tharang, A., Dettmann, S., Roloff, A., 2015. Role of street trees in mitigating effects of heat and drought at highly sealed urban sites. Landscape Urban Plan., 143, 33-42. https://doi.org/10.1016/j.landurbplan.2015.06.005

Guan, H.J., Liu, X.Y., 2021. Biocrust effects on soil infiltrability in the $\mathrm{Mu}$ Us Desert: Soil hydraulic properties analysis and modeling. J. Hydrol. Hydromech., 69, 4, 378-386.

Harper, K.T., Marble, J.R., 1988. A role for nonvascular plants in management of arid and semiarid rangelands. In: Tuller, P.T. (Ed.): Applications of Plant Sciences to Rangeland Management and Inventory. Kluwer, Amsterdam, pp. 135-169.

Hazen, R.M., Papineau, D., Bleeker, W., Downs, R.T., Ferry, J.M., McCoy, T.J., Sverjensky, D.A., Yang, H., 2008. Mineral evolution. Am. Mineral., 93, 1693-1720.

Heusinkveld, B.G., Berkowicz, S.M., Jacobs, A.F.G., Holtslag, A.A.M., Hillen, W.C.A.M., 2006. An automated microlysimeter to study dew formation and evaporation in arid and semiarid regions. J. Hydrometeorol., 7, 825-832.

Jančo, M., Mezei, P., Kvas, A., Danko, M., Sleziak, P., Mind'áš, J., Škvarenina, J., 2021. Effect of mature spruce forest on canopy interception in subalpine conditions during three growing seasons. J. Hydrol. Hydromech., 69, 4, 436446.

Kidron, G.J., 2009. The Effect of shrub canopy upon surface temperatures and evaporation in the Negev Desert. Earth Surf. Process. Landf., 34, 123-132. https://doi.org/10.1002/esp.1706

Kidron, G.J., 2019. The dual effect of sand-covered biocrusts on annual plants: Increasing cover but reducing individual plant biomass and fecundity. Catena, 182, 104120. https://doi.org/10.1016/j.catena.2019.104120

Kidron, G.J., 2021. The role of biocrust-induced exopolymeric matrix in runoff generation in arid and semiarid zones - a mini review. J. Hydrol. Hydromech., 69, 4, 360-368.

Kidron, G.J., Yaalon, D.H., Vonshak, A., 1999. Two causes for runoff initiation on microbiotic crusts: hydrophobicity and pore clogging. Soil Sci., 164, 18-27.

Kidron, G.J., Herrnstadt, I., Barzilay, E., 2002. The role of dew as a moisture source for sand microbiotic crusts in the Negev Desert, Israel. J. Arid Environ., 52, 517-533. https://doi.org/10.1006/jare.2002.1014

Klanderud, K., 2008. Species-specific responses of an alpine plant community under simulated environmental change. J. Veg. Sci., 19, 363-372. https://doi.org/10.3170/2008-818376

Lange, B., Luescher, P., Germann, P.F., 2009. Significance of tree roots for preferential infiltration in stagnic soils. Hydrol. Earth Syst. Sci., 13, 1809-1821.

Lázaro, R., Calvo-Cases, A., Arnau-Rosalén, E., Rubio, C., Fuentes, D., López-Canfín, C., 2021. Defining minimum runoff length allows for discriminating biocrusts and rainfall events. J. Hydrol. Hydromech., 69, 4, 387-399.

Leelamanie, D.A.L., Piyaruwan, H.I.G.S., Jayasinghe, P.K.S.C., Senevirathne, P.A.N.R., 2021. Hydrophysical characteristics in water-repellent tropical Eucalyptus, Pine, and Casuarina plantation forest soils. J. Hydrol. Hydromech., 69, 4, 447-455.

Lichner, L., Hallett, P.D., Orfánus, T., Czachor, H., Rajkai, K., Šir, M., Tesař, M., 2010. Vegetation impact on the hydrology of an aeolian sandy soil in a continental climate. Ecohydrology, 3, 413-420. https://doi.org/10.1002/eco.153
Lichner, L., Hallett, P.D., Drongova, Z., Czachor, H., Kovacik, L., Mataix-Solera, J., Homolák, M., 2013. Algae influence the hydrophysical parameters of a sand soil. Catena, 108, 58-68. https://doi.org/10.1016/j.catena.2012.02.016

Littmann, T., Veste, M., 2008. Evapotranspiration, transpiration and dewfall. In: Breckle, S.-W, Yair, A.,Veste, M. (Eds.), Arid Dune Ecosystems: The Nizzana Sands in the Negev Desert, Ecological Studies 200, Springer, Berlin Heidelberg New York, pp. 183-200. https://doi.org/10.1007/978-3540-75498-5_13

Miralles, D.G., Gash, J.H., Holmes, T.R.H., de Jeu, R.A.M., Dolman, A.J., 2010. Global canopy interception from satellite observations. J. Geophys. Res., 145, D16. https://doi.org/10.1029/2009JD013530

Muselli, M., Beysens, D. 2021. Mapping past, present and future dew and rain water resources for biocrust evolution in southern Africa. J. Hydrol. Hydromech., 69, 4, 400-420.

Or, D., Phutane, S., Dechesne, A., 2007. Extracellular polymeric substances affecting pore-scale hydrologic conditions for bacterial activity in unsaturated soils. Vadose Zone J., 6, 298-305. https://doi.org/10.2136/vzj2006.0080

Root, T.L., Price, J.T., Hall, K.R., Schneider, S.H., Rosenzweig, C., Pounds, J.A., 2003. Fingerprints of global warming on wild animals and plants. Nature, 421, 57-60.

Simonin, K.A., Santiago, L.S., Dawson, T.E., 2009. Fog interception by Sequoia sempervirens (D. Don) crowns decouples physiology from soil water deficit. Plant Cell Environ., 32, 882-892. https://doi.org/10.1111/j.13653040.2009.01967.x

Thielen, S.M., Gall, C., Ebner, M., Nebel, M., Scholten, T., Seitz, S., 2021. Water's path from moss to soil: A multimethodological study on water absorption and evaporation of soil-moss combinations. J. Hydrol. Hydromech., 69, 4, 421-435.

Turbé, A., De Toni, A., Benito, P., Lavelle, P., Lavelle, P., Ruiz, N., van der Putten, W.H., Labouze, E., Mudgal, S., 2010. Soil biodiversity: Functions, threats and tools for policy makers. Technical Report 2010-049. European Communities. https://doi.org/10.2779/14571

Vereecken, H., Schnepf, A., Hopmans, J.W., Javaux, M., Or, D., Roose, T., Vanderborght, J., Young, M.H., Amelung, W., Aitkenhead, M., Allison, S.D., Assouline, S., Baveye, P., Berli, M., Brüggemann, N., Finke, P., Flury, M., Galser, T., Govers, G., Ghezzehei, T., Hallett, P., Hendricks Franssen, H.J., Heppell, J., Horn, R., Hulsman, J.A., Jacques, D., Jonard, F., Kollet, S., Lafolie, F., Lamorski, K., Leitner, D., McBratney, A., Minasny, B., Montzka, C., Nowak, W., Pachepsky, Y., Padarian, J., Romano, N., Roth, K., Rothfuss, Y., Rowe, E.C., Schwen, A., Ŝimůnek, J., Tiktak, A., Van Dam, J., van der Zee, S.E.A.T.M., Vogel, H.J., Vrugt, J.A., Wöhling, T., Young, I.M., 2016. Modeling soil processes: Review, key challenges, and new perspectives. Vadose Zone J., 15, 1-57. https://doi.org/10.2136/vzj2015.09.0131

Veste, M., Heusinkveld, B.G., Berkowicz, S.M., Breckle, S.W., Littmann, T., Jacobs, A.F.G., 2008. Dew formation and activity of biological soil crusts. In: Breckle, S.-W., Yair, A., Veste, M. (Eds.). Arid Dune Ecosystems: The Nizzana Sands in The Negev Desert. Ecological Studies 200. Springer, Heidelberg, Germany, pp. 305-318. https://doi.org/10.1007/978-3-540-75498-5_21

Zabret, K., Šraj, M., 2021. Relation of influencing variables and weather conditions on the rainfall partitioning by birch and pine trees. J. Hydrol. Hydromech., 69, 4, 456-466. 